Int. J. Dev. Biol. 54: 313-322 (2010)

doi: $10.1387 / \mathrm{ijdb} .082772 \mathrm{ed}$

\title{
Local regulation of implantation at the human fetal-maternal interface
}

\author{
EVDOKIA DIMITRIADIS\#, GUIYING NIE\#, NATALIE J. HANNAN, PREMILA PAIVA and LOIS A. SALAMONSEN* \\ Prince Henry's Institute of Medical Research, Clayton, Victoria, Australia
}

\begin{abstract}
Embryo implantation and formation of a functional placenta are complex processes that require a plethora of regulatory molecules. In recent years, many of these mediators have been identified, often from studies in experimental animals. Furthermore, their expression patterns at the embryo-maternal interface in women have been characterized and provide clues to their potential actions. What has been missing in most cases is any experimental demonstration of their function. Proteases, cytokines and chemokines are among the molecules identified at the embryo-maternal interface. Functional studies of the protease, proprotein convertase (PC)6, the gp130 cytokines, leukemia inhibitory factor (LIF) and interleukin (IL) 11 and the chemokines, CX3CL1 and CCL14 demonstrate potential actions within the uterine cavity. These actions include: enhancing blastocyst development, modifying adhesive properties of the blastocyst and the uterine epithelial surface, and providing chemotactic guidance to the blastocyst. As implantation proceeds, PC6 and IL-11 also act to drive decidualization. The products (proteases, chemokines and cytokines) produced by these decidual cells provide a unique environment. This is important for both directing and restraining trophoblast invasion and for leukocyte trafficking into the decidua until the placenta is fully established.
\end{abstract}

KEY WORDS: PC6, LIF, IL-11, chemokine, trophoblast, endometrium

\section{Introduction}

Implantation in humans is a continuum, starting with apposition and attachment of the blastocyst to the apical surface of the endometrial luminal epithelium and continuing throughout the first trimester of pregnancy until the extravillous trophoblast taps into and remodels the maternal vasculature. A plethora of regulatory molecules have been demonstrated to play functional roles in many of the processes, including preparation of the endometrial stroma (decidualization) and epithelium for implantation and control of trophoblast adhesion, invasion and directional trafficking. These regulatory molecules include cytokines, chemokines and proteases, many of which are expressed in different cell types and with slightly different functions as implantation progresses. Although initial functional studies demonstrating critical functions at implantation have been performed in mice or in other mammalian species with different forms of placentation, subsequent studies of expression patterns in women, in whom in vivo functional studies are not possible, suggest that the same molecules have been adapted at various stages of implantation. This review will examine the evidence for roles for members of these three important classes of regulatory molecules at different stages during implantation in women (Fig. 1).

\section{Proteases that regulate bioactivities of regulatory molecules: proprotein convertases}

Biologically active proteins and peptides are often generated through post-translational modifications following gene transcription and protein synthesis. One such important modifica-

\footnotetext{
Abbreviations used in this paper: ECM, extracellular matrix; EVT, extravillous trophoblast; HB-EGF, heparin bound epidermal growth factor; HESC, human endometrial stromal cell; HSPG, heparan sulfate proteoglycans; IGFBP, insulin-like growth factor binding protein; IL-11, interleukin 11; IL-11R $\alpha$, interleukin 11 receptor $\alpha$; JAK/STAT, janus kinase/signal transducer and activator of transcription; LIF, leukemia inhibitory factor; LIF-R, leukemia inhibitory factor receptor; MAPK, mitogen-activated protein kinase; MMP, matrix metalloproteinase; NK cells, natural killer cells; PC, proprotein convertase; SOCS, suppressor of cytokine signaling; TIMP, tissue inhibitor of metalloproteinases.
}

\footnotetext{
*Address correspondence to: Lois A. Salamonsen. Prince Henry's Institute of Medical Research, PO Box 5152 , Clayton 3168 Victoria, Australia. Fax +61-3-9594-6125. e-mail: lois.salamonsen@princehenrys.org - http://www.princehenrys.org
}

\# Note: Equal contribution as first author.

Final author-corrected PDF published online: 11 September 2009.

ISSN: Online 1696-3547, Print 0214-6282 
tion is limited proteolysis which converts precursor proteins into their active forms. The most critical enzymes responsible for proteolytic activation of precursor proteins are seven closely related serine proteases (furin, PC1/3, PC2, PC4, PACE4, PC5/ $6, \mathrm{PC} 7 / \mathrm{PC} 8 / \mathrm{LPC})$ known as proprotein convertases (PCs) (Bergeron et al., 2000; Fugere and Day, 2005; Seidah and Chretien, 1999; Seidah et al., 2008). PCs post-translationally process and hence regulate the temporal and spatial activation of a large number of pro-proteins, including growth factors, peptide hormones, neuropeptides, ECM proteins, adhesion molecules, proteolytic enzymes, and integral membrane proteins through a controlled proteolytic cleavage at basic residues (usually arginines) within the general motif of $(K / R)-(X) n-(K / R) \downarrow$ (where $n=0,2$, 4 or $6, X$ is any amino acid, and $\downarrow$ indicates the site of cleavage) (Seidah and Chretien, 1999). PCs are thus regarded as "master switch" molecules and recognized as promising targets for therapeutic approaches.

Gene discovery studies, especially through the use of microarray and proteomics technologies, have identified a number of genes and their protein products that are important for implantation (Carson et al., 2002; Giudice, 2003; Giudice and Irwin, 1999; Kao et al., 2002; Riesewijk et al., 2003; Sharkey and Smith, 2003). These include cell surface proteins (eg. selectins), ECM components (eg. proteoglycans), tissue remodeling proteases (eg. metalloproteinases), cell adhesion molecules (eg. integrins), vasoactive factors (eg. prostaglandins), growth factors (eg. epidermal growth factor), cytokines (eg. leukemia inhibitory factor) and

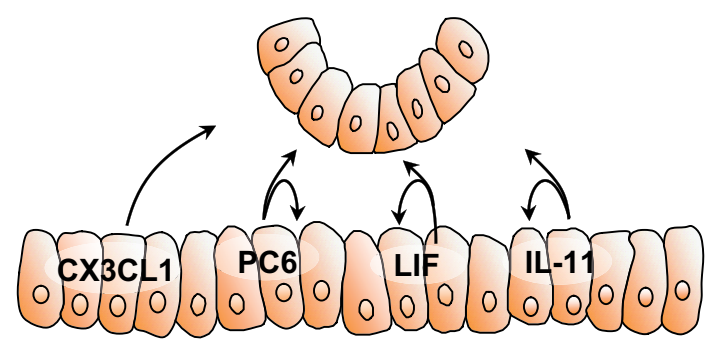

blastocyst

uterine cavity

endometrial epithelium

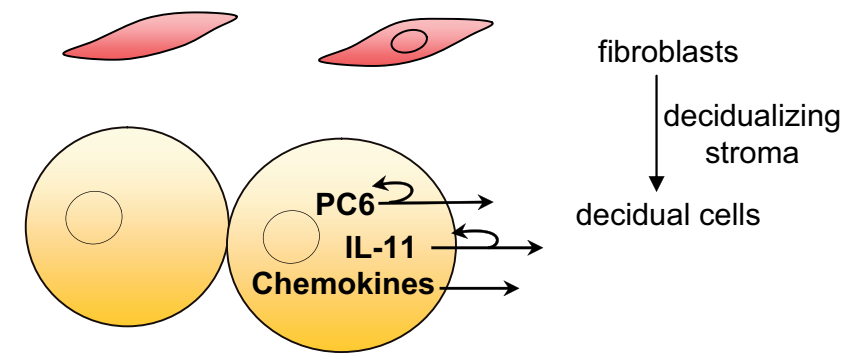

Fig. 1. Molecular interactions at implantation. Interactions between the blastocyst/trophoblast, uterine epithelium and decidualized stromal cells at implantation are in part mediated by the cytokines, interleukin 11 and LIF, and chemokines including CX3CL 1 which are released into the uterine cavity: their receptors are present on the blastocyst. The cytokines also act in an autocrine manner on the epithelium. PC6, an enzyme that processes molecules to their biologically active forms, is likewise produced in the receptive epithelium. Such mediators are also produced by decidualizing stromal cells: PC6 and IL-11 are critical for decidualization, while the secreted chemokines play important roles in both leukocyte and trophoblast trafficking through the decidual compartment. peptide hormones (eg. calcitonin). Many of these proteins are synthesized initially as inactive precursor proteins and require post-translational activation.

One of the PCs, PC6, was identified as being dramatically upregulated in the mouse uterus at implantation, with the upregulation being implantation site specific, transient and coinciding with the time of embryo attachment and implantation (Nie et al., 2003). When PC6 protein synthesis was knocked down in the uterus using antisense morpholino oligos (designed to target the initiation site for PC6 protein translation), prior to the expected time of PC6 up-regulation during early pregnancy, implantation was completely inhibited (Nie et al., 2005b). Thus endometrial PC6 is critical for implantation in the mouse.

\section{Gp130 cytokines: LIF and IL-11}

The gp130 cytokines (which include leukemia inhibitory factor (LIF) and interleukin (IL)-11) share an accessory signal transducing subunit gp130 while having separate specific low affinity $\alpha$ receptor $(\mathrm{R})$ subunits. Binding of each cytokine to its cognate $\mathrm{R} \alpha$ triggers dimerization with gp130, forming a high affinity receptor and leading to activation of the janus kinase/signal transducer and activator of transcription (JAK/STAT) signal transduction pathway (Heinrich et al., 1998). Signal transduction is attenuated via the suppressors of cytokine signaling (SOCS) family of cytoplasmic proteins that complete a negative feedback loop (Stewart et al., 1992).

LIF and IL-11 have both been implicated as critical players in the implantation process. LIF was the first cytokine to be shown to be essential for implantation in mice (Stewart et al., 1992). LIF is upregulated in the uterine epithelium just prior to implantation and mice null for the LIF gene fail to become pregnant. However, LIF-null embryos transplanted into wild-type mothers implant and develop normally, proving that it is endometrial LIF that is needed for implantation (Bhatt et al., 1991). Mice lacking the receptor for IL-11 also have a fertility defect, which, unlike that in the LIF deficient mice, occurs in the post-implantation response to the implanting blastocyst and results from defective decidualization of the endometrial stroma (Bilinski et al., 1998; Robb et al., 1998).

\section{Chemokines: CX3CL1 and CCL14}

Chemokines are small chemotactic cytokines, best known as key regulators of leukocyte recruitment and activation. There are more than 50 chemokines and a lesser number of specific receptors: thus there is promiscuous ligand-receptor binding, considerable redundancy and overlap of functions. Although first identified for their role in leukocyte trafficking, a number of chemokines and their receptors have recently been identified at the fetal-maternal interface (reviewed in Hannan and Salamonsen, 2007) suggesting roles in implantation. These include CX3CL1 (also known as fractalkine) and CCL14 (also known as HCC-1). CX3CL1, exists as both a membrane-anchored adhesion molecule that can capture/coordinate leukocyte migration in an integrin- and selectin-independent manner, and as a soluble chemotactic peptide that cleaves from the cell surface. Unusually, the binding of $C X 3 C L 1$ to its receptor CX3CR1, is highly specific. CCL14 exists in a range of proteolytically processed forms which have different agonist activities for its receptors, CCR1 and CCR5. Both chemokines are produced maximally by the human endometrium at the time of embryo implantation and during early 
pregnancy (Hannan et al., 2004; Jones et al., 2004) while their receptors are present on trophoblast (Hannan etal., 2006) providing an opportunity for functions in directional trophoblast migration as well as in leukocyte migration to the implantation site.

\section{Roles of endometrial factors during implantation}

\section{Factors produced by endometrial epithelium during the 'win- dow of receptivity'}

In women, the endometrium is receptive to implantation only during a very short period of time in the mid-secretory phase of each menstrual cycle; this is known as the 'window of receptivity'. Under the influence of progesterone, the epithelial cells become highly secretory: indeed analysis of uterine fluid and data from immunohistochemical studies indicate that regulatory molecules including LIF (Laird et al., 1997), CX3CL1 and CCL14 (Hannan et al., 2004; Jones et al., 2004) are released into the uterine lumen where they can affect the blastocyst even prior to attachment. Other changes to the luminal epithelium include alterations to cell surface glycoconjugates such as mucins (Aplin et al., 2001; Gipson et al., 2008), and to adhesion molecules on both apical and lateral membranes (Aplin, 1997; Murphy, 2004). In women, PC6, LIF, IL-11, CX3CL1 and CCL14 are all maximally expressed in the luminal and glandular epithelium during the mid-secretory phase of the menstrual cycle (see below). Interestingly, this expression pattern for PC6 and IL-11 is different from that seen in mice, in which these molecules are detected only in decidual cells as decidualization of the stroma proceeds, most likely reflecting the much higher importance of the epithelium during implantation in women: in mice the epithelium is lost immediately following attachment. The potential importance of epithelial production of such factors is emphasized by the reduced intensity of epithelial immunostaining for LIF and IL-11 in certain women with infertility (Dimitriadis et al., 2007a; Dimitriadis et al., 2006a).

In the rhesus monkey, PC6 is expressed in the glandular epithelium during a conception cycle, but the expression is dramatically increased at the expected time of implantation (Nie et al., 2005b). In the human, PC6 expression in the epithelium is also increased significantly in the mid-secretory phase in anticipation of implantation (Nie et al., 2005b). We have also investigated the expression of the other PC family members in the human endometrium (Freyer etal., 2007). RT-PCR detected endometrial expression of mRNA for furin, PACE4, PC4 and PC7, but a negligible level for PC1/3 and PC2. None, however, showed clear up-regulation at the expected time of implantation. Furin, PACE4 and PC7 were immunolocalized to the epithelium with no apparent up-regulation in the mid-secretory phase.

In endometrium of women of proven fertility, LIF mRNA is expressed during days 18 to 28 of the menstrual cycle (Arici et al., 1995; Charnock-Jones et al., 1994; Dimitriadis et al., 2000; Kojima et al., 1994; Sharkey et al., 1995; Vogiagis et al., 1996). Both LIF mRNA and protein are localized in uterine glandular and luminal epithelium (Sharkey et al., 1995; Vogiagis et al., 1996), with immunoreactive protein being maximal in both luminal and glandular epithelium between day $\mathrm{LH}+6$ and +9 coinciding with pinopode formation (Aghajanova et al., 2003). Immunoreactive LIF has also been observed in stroma (Aghajanova et al., 2003; Baird et al., 1996; Danielsson et al., 1997; Vogiagis et al., 1996). LIF-R immunostaining is also maximal in both luminal and glan- dular epithelium between day $\mathrm{LH}+6$ and +9 (Aghajanova et al., 2003).

It appears that progesterone is a major regulator of LIF expression in primates. Not only does endometrial expression coincide with progesterone domination of the tissue, but treatment of women with the progesterone receptor antagonist, mifepristone (RU486) immediately after ovulation, reduces LIF immunoreactivity at the expected time of implantation (Danielsson et al., 1997). However, locally produced factors, including heparin bound epidermal growth factor (HB-EGF) (Arici et al., 1995; Lessey, 2002) prokineticin 1 (Evans et al., 2008) and human chorionic gonadotrophin (Licht et al., 2007; Perrier d'Hauterive et al., 2004) have been shown to regulate LIF secretion by cultured endometrial epithelial cells in culture and its production in vivo. Interestingly, p53 which is widely known for its function as a tumor suppressor, regulates transcription of the mouse endometrial Lif gene, probably by interaction with the estrogen receptor (Hu et al., 2007); whether this is the case also in women remains to be determined.

The biological actions of endometrial LIF are not yet fully understood although evidence suggests that LIF is important for human fertility. The glandular expression indicates likely secretion into the uterine lumen and indeed LIF protein is maximal in uterine flushings in the mid-late secretory phase of the menstrual cycle at the time of expected implantation in fertile women. This is reduced in flushings from women with unexplained fertility (Laird et al., 1997; Ledee-Bataille et al., 2002). Should LIF be released also basally from uterine epithelium, paracrine effects on the underlying stroma and leukocytes would be possible. To support this data, endometrial explants from infertile women secrete less LIF compared to biopsies from fertile women (Delage et al., 1995); however, the effects of culture on cytokine production from explants were not taken into account. Another study revealed that LIF mRNA levels did not differ between fertile and infertile women (Sherwin et al., 2002) although higher levels of soluble gp130 were found, suggesting inhibition of LIF action. LIF immunostaining is also reduced in endometrium of women who were infertile compared to fertile women (Tsai et al., 2000) and in a cohort of women with infertility and endometriosis (Dimitriadis et al., 2006a).

IL-11 is also expressed in glandular and luminal epithelium in mid-secretory phase endometrium suggesting a role in uterine receptivity (Cork et al., 2001; Dimitriadis et al., 2000) while prokineticin 1, which provides a potent stimulus for IL-11 production is likewise produced in endometrial epithelium (Evans et al., 2008). Importantly, IL-11R $\alpha$ and gp130 are also expressed in both luminal and glandular epithelium in the mid secretory phase (Cork et al., 2002; Cullinan et al., 1996). However, it appears that there is no cyclical variation in IL-11R $\alpha$ expression and thus the expression pattern of ligand may be critical for IL-11 function in the endometrium. IL-11 is decreased in peri-implantation endometrium of excessive ovarian responders during IVF treatment suggesting that IL-11 is involved in the establishment in pregnancy, since high responders lead to failed IVF pregnancies (Makkar et al., 2006). Furthermore, both IL-11 and IL-11R $\alpha$ are reduced in the glands of some women with infertility and endometriosis (Dimitriadis et al., 2006a), suggesting that disturbance of the production of IL11 and its local action may result in infertility. It remains to be evaluated whether epithelial-derived IL-11 is secreted apically 
into the uterine lumen or basally into the stroma.

An abundance of literature exists regarding chemokine expression in the endometrium, mostly focused on individual chemokines. However, the most abundant chemokines in the non-pregnant endometrium were recently identified using a nonbiased gene array screen and tissue from all stages of the menstrual cycle. Among the chemokines subsequently validated by immunohistochemistry (summarized in Hannan and Salamonsen, 2007), and found to be elevated particularly in the epithelium during the mid-secretory phase of the cycle, were CCL8, CX3CL1, CCL4 and CCL14 (Hannan et al., 2004; Jones et al., 2004). Importantly, these are all chemoattractants for macrophages and all but CCL14 can also recruit natural killer cells: both these leukocyte subsets start to rise in number in the endometrium in the mid-secretory phase. However, the epithelial location of expression suggests alternative functions for these chemokines at implantation. Roles for chemokine action later in pregnancy have been proposed: these include cytotrophoblast targeting to maternal spiral arterioles and novel immune mechanisms for fetal allo-transplantation (Red-Horse et al., 2001).

\section{Factors of importance for decidualization}

Decidualization can be defined as the process whereby endometrial stromal cells differentiate into a quite different cell type, the decidual cell, which along with specific leukocytes (uterine natural killer (NK) cells and macrophages) and altered blood vessels comprise the decidua of pregnancy. In the human, this process is initiated in the mid-secretory phase of each menstrual cycle, and when progesterone levels are maintained in early pregnancy, it continues throughout the pregnancy to maintain the decidua. IL-11 and PC6 mRNA and protein are strongly expressed in the decidualizing / decidualized stromal cells which start to appear in the normal menstrual cycle during the mid-late secretory phase: immunostaining for these factors is further enhanced in first trimester decidua. Both factors have been shown to be essential for decidualization.

\section{Actions of interleukin 11}

Decidualization in mice does not progress in the absence of IL11 action (Robb et al., 1998) while in women, IL-11 advances in vitro progesterone-induced decidualization of endometrial stromal cells (Dimitriadis et al., 2002). Upregulation of IL-11 mRNA has been detected by gene array during progesterone or cAMP induced in vitro decidualization of endometrial stromal cells (Popovici et al., 2000; Tierney et al., 2003). Since both IL-11 and IL-11R $\alpha$ immunolocalize in decidualized stromal cells of mid-late secretory phase endometrium in the human, it is likely that the action of IL-11 during decidualization is paracrine or autocrine (Cork et al., 2002; Dimitriadis et al., 2002). IL-11 secretion and mRNA expression by human endometrial stromal cells are stimulated by locally produced factors, relaxin and prostaglandin $E_{2}$. acting at least in part via cAMP during human endometrial stromal cell decidualization (Dimitriadis et al., 2005). Importantly, IL-11 and progesterone mediated pathways converge during human endometrial stromal cell (HESC) decidualization (Dimitriadis et al., 2006b). Progesterone stimulates both STAT3 protein (which is then phosphorylated upon activation of the IL-11 receptor complex) and SOCS3 protein (which attenuates IL-11 action and provides a feed-back loop) during decidualization. IL-11 initiates and progresses decidualization of HESC via pSTAT3 and SOCS3 (Dimitriadis et al., 2006b) leading to highly regulated expression of other endometrial proteins associated with decidualization. In particular, IL-11 inhibits IGFBP-5 production and stimulates latent but not active IL-1 $\beta$ during decidualization of HESC (White et al., 2005; White et al., 2007). Importantly, IL-11 secretion is reduced during decidualization from HESC isolated from infertile women compared to fertile women (Karpovich et al., 2005).

\section{Actions of proprotein convertase 6}

Likewise, endometrial PC6 is critical for decidualization and hence implantation in the mouse: when PC6 protein synthesis was knocked down using antisense morpholino oligos (designed to target the initiation site for PC6 protein translation), prior to the expected time of PC6 up-regulation during early pregnancy, implantation was completely inhibited (Nie et al., 2005b). Endometrial PC6 (mRNA and protein) expression is also tightly associated with stromal cell decidualization both in the rhesus monkey and human (Nie etal., 2005b). In the human, stromal PC6 expression is detected only in the decidual cells when decidualization occurs spontaneously prior to implantation during the menstrual cycle, and the decidual PC6 expression intensifies with the establishment of implantation. In the monkey, no stromal PC6 expression was detected during the menstrual cycle as no decidualization occurs spontaneously, but PC6 is highly expressed in decidual cells at implantation sites during early pregnancy (Nie et al., 2005a).

Investigation of the expression of the other PC family members in the stromal cells across the menstrual cycle has not shown particular association of their expression with decidualization. Unlike PC6 which is localized specifically to decidual cells, furin, PACE4 and PC7 were localized to both non-decidualised and decidualised stromal cells. The lack of association of PCs other than PC6 with decidualization was further confirmed in an in vitro decidualization model using primary endometrial stromal cells isolated from human endometrial tissues (Freyer et al., 2007; Okada et al., 2005). Subsequently, the in vitromodel was used to determine PC6's importance for decidualization (Nie etal., 2005b). Knocking down of PC6 in stromal cells during the course of

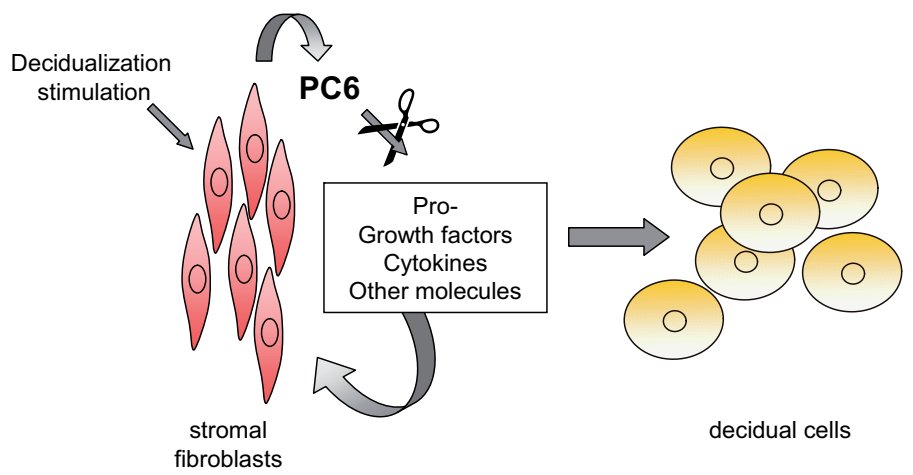

Fig. 2. PC6 is pivotal in human stromal cell decidualization. PC6 expression is first seen in stromal cells as they start to decidualize and is critical for this process. Its proteolytic activity cleaves pro-forms of certain growth factors and cytokines and other molecules (particularly caldesmon and tropomyosin) to produce biologically active forms that are essential as decidualization proceeds. 
decidualization significantly inhibited the process of decidualization (Okada et al., 2005), providing evidence that PC6 is critical for decidualization of in the human (Fig. 2).

An important remaining question is what substrates are cleaved by PC6 during decidualization? Two dimensional differential in gel electrophoresis of decidualized stromal cell lysates that had or had not been treated with active PC6 in vitro, recently identified caldesmon, tropomyosin-2 and tropomyosin-4 as being cleaved by PC6. In confirmation, caldesmon co-localizes with PC6 in decidual cells in the human endometrium in vivo(Nie et al., 2008). Since caldesmon and tropomyosin are structural proteins previously found to be involved in actin filament reorganization, it appears that at least one action of PC6 is as a mediator of the structural remodeling of stromal cells during decidualization.

\section{Decidual chemokines}

Many chemokines are very strongly expressed in decidualized stromal cells (but not in non-decidualized stromal cells) (Hannan et al., 2004; Jones et al., 2004) and these appear to be among the molecules regulated by the 'molecular switch' which dramatically changes the phenotype of stromal cells as they decidualize. Importantly, expression of some of these (CXCL1, CXCL2, CCL8) can be further increased in decidualized stromal cells in culture following exposure to culture medium from trophoblast cells (Hess et al., 2007).

\section{Regulation of trophoblast function by factors of endometrial epithelial origin}

\section{Uterine fluid: influence on blastocyst development}

The content of uterine fluid is likely to be of considerable importance in providing an optimal environment for pre-implantation blastocyst development, apposition and attachment; whether reduced levels of any individual factor play a key role in failure of blastocyst attachment and invasion remains to be established. While the high number and complexity of proteins present in uterine fluid is apparent when such fluid is analysed by two dimensional gel electrophoresis, the identity of most of these proteins is currently unknown; the most abundant are serum proteins (Parmar et al., 2008). Whether these serum proteins are important for the blastocyst is not yet known.

A number of cytokines have been detected in uterine fluid by individual assay: these include LIF (Laird et al., 1997; Mikolajczyk et al., 2003), activin A (Florio et al., 2003) and IL-18 (LedeeBataille, 2004) while recent analysis using Luminex technology has confirmed the presence of an abundance of cytokines, but with considerable variability between individuals (Boomsma et al., 2008). There is also suggestive evidence that many other regulatory molecules are secreted from endometrial epithelial cells into the uterine lumen at the time of implantation. For example, certain chemokines including CX3CL1 and CCL8 are immunodetected first in the glands in the early secretory phase where they appear to be localized basally within the cells. As the cycle progresses into the mid-secretory phase, the protein becomes localized to the apical surface of these cells and can be detected also within the lumen of the glands (Fig. 3). Whether IL11 or PC6 are secreted into the uterine lumen is not yet known: it is possible that the secreted form of PC6 could act on soluble substrates within the uterine cavity to regulate their bioactivity.
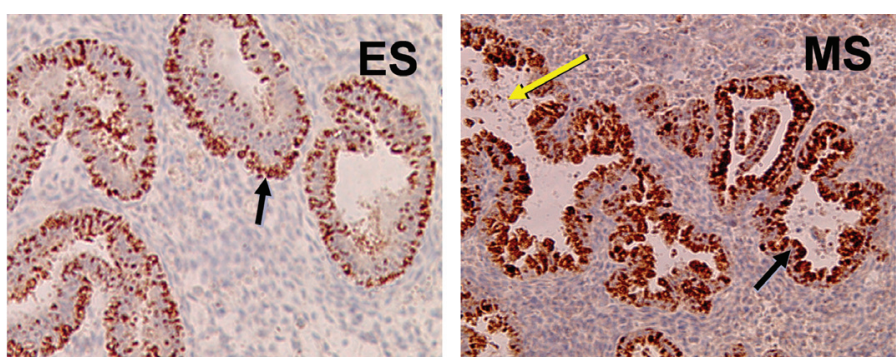

Fig. 3. Immunostaining for CCL7 in secretory phase endometrium. The pattern of staining (brown) suggests secretion into the uterine lumen. Immunoreactive CCL7 is highly expressed during the early secretory phase (ES) of the cycle, basally in glandular and luminal epithelial cells (black arrow). By the mid-secretory phase (MS), the protein is identified towards the apical surface of these cells (black arrow) and also within the lumen of the glands (yellow arrow). (Reproduced with permission from Jones et al., 2004).

Stage specific expression of a number of cytokine receptors occurs on pre-implantation embryos (Sharkey et al., 1995). Interestingly, while mRNA encoding receptors for c-fms and c-kit (receptors for colony-stimulating factor-1 and stem-cell factor respectively) appears not to be stage-specific, mRNA for the LIF receptor (LIF-R), IL-6 receptor and gp130, do not appear until the blastocyst stage, suggesting differing roles for the specific ligands. In confirmation, blastocysts produced by in vitro fertilization and cultured to the peri-implantation stage likewise express LIF-R transcripts (Charnock-Jones et al., 1994). In vitro, LIF promotes human blastocyst formation rates of human embryos cultured in serum-free medium (Dunglison et al., 1996); whether LIF exerts similar or additional effects on human pre-implantation blastocysts in vivo is not yet known.

Chemokine receptors (specifically CCR2B and CCR5) are also present on the pre-implantation blastocyst (Dominguez et al., 2003): it may be that other receptors are also present. However identification of receptors and actions of their ligands on human blastocysts is limited by the very restricted access to these worldwide and most studies have therefore been carried out on trophoblast cell lines, that generally reflect somewhat later stages of trophoblast development (Hannan et al., 2009). Chemokines present in uterine fluid are likely to set up concentration gradients to assist blastocyst apposition, while their actions on trophoblast adhesion that have been demonstrated in cell lines (Hannan and Salamonsen, 2008), may represent actions on pre-implantation blastocysts.

\section{Uterine epithelium: interaction with trophoblast during adhesion and attachment}

Changes to the luminal epithelium are necessary for successful implantation. In particular, these include changes to the apical surface to facilitate attachment and alterations at the lateral surface to facilitate penetration of trophoblast between the epithelial cells.

PC6 is known to process a number of adhesion related molecules including integrins (Lissitzky et al., 2000; Stawowy et al., 2004) and neural adhesion protein-L1 (Kalus et al., 2003). It was recently demonstrated that PC6 interacts with heparan sulfate proteoglycans (HSPGs), thereby recruiting itself to the cell surface where it can activate a number of HSPG-bound substrates 
both at the cell surface or in the extracellular space (Mayer et al., 2008; Seidah et al., 2008). Experiments are needed to identify which proteins PC6 actually activates in the endometrial epithelium, but it is tempting to speculate that PC6 likely regulates adhesion molecules and other cell surface proteins during the establishment of endometrial receptivity, to facilitate epithelialtrophoblast interaction for embryo attachment and implantation.

Functional roles for both LIF and IL-11 on the uterine epithelium during the peri-implantation period have recently been demonstrated. IL-11 stimulates (but LIF has no effect on) the adhesion of human trophoblast to human endometrial epithelial cells, possibly by its demonstrated stimulation of epithelial integrin $\alpha 2$ mRNA and protein (Marwood et al., 2009). By contrast, both IL-11 and LIF stimulate the adhesion of primary human endometrial epithelial cells to fibronectin via phosphorylation of STAT3, actions that are abolished by specific inhibitors (Dimitriadis et al., 2007b). The contraceptive potential of blocking LIF action in the uterus has also been demonstrated. Administration of a longacting LIF antagonist blocked LIF action in the uterine luminal epithelium and prevented implantation in mice (White et al., 2007).

\section{Uterine decidual cells: interaction with trophoblast during invasion}

Once the trophectoderm has breached the uterine epithelium and formed a syncytium, certain extravillous trophoblast (EVT) cells break through the syncytium and migrate and invade through the maternal decidua to eventually establish a blood supply for the fetus. In humans, trophoblast invasion is unusually aggressive; interstitial EVT invade up to the first third of the uterine myometrium and home to the vicinity of the spiral arteries which they invade (becoming endovascular EVT) and remodel. Extensive communication between trophoblast subtypes and endometrial cells is required for the entire invasive process. Furthermore, the decidua plays an important role in restraining trophoblast invasion which can be lethal if it occurs outside of the uterus.

During pregnancy, LIF and LIF-R have been detected in the decidua and chorionic villi of first-trimester and term placenta in humans (Kojima et al., 1994; Kojima et al., 1995; Sawai et al., 1995; Sawai et al., 1997; Sharkey et al., 1999). LIF-R mRNA and immunoreactivity localizes in both villous and extravillous trophoblast throughout pregnancy, and in endothelial cells of the fetal villi (Sharkey et al., 1999). Strong expression of mRNA encoding LIF has also been detected in decidual leukocytes, which are abundant at the implantation site, suggesting that LIF may mediate interactions between maternal decidual leukocytes and invading trophoblast cells (Sharkey et al., 1999).

Recent data supports a role for LIF in adhesion and differentiation of trophoblast cells to the invasive phenotype. Both of these are involved in trophoblast invasion, a process that if not finely regulated can result in abnormal placentation. Indeed, an abnormally persistent expression of LIF receptor on EVT cells in placental bed biopsies has been demonstrated in patients with early onset pre-eclampsia combined with intrauterine growth retardation (Reister et al., 2006). In functional studies, LIF increased EVT cell adhesion to fibronectin, vitronectin and laminin (Fig. 4A) (Tapia et al., 2008) and decreased integrin $\beta 4$ mRNA levels compared to controls. Although matrix metalloproteinase (MMP)2 and MMP9 secretion from EVT were not affected, LIF increased secretion of tissue inhibitor of metalloproteinases (TIMP)-1, thus altering the MMP/TIMP balance. These data therefore suggest a local mechanism for decidual cell restraint of invasion.

Both IL-11 and IL-11 receptor $\alpha(\mathrm{R} \alpha)$ mRNA and protein are present in decidual cells during early pregnancy (Chen et al., 2002; Cork et al., 2002; Dimitriadis et al., 2003; Dimitriadis et al., 2002; Karpovich et al., 2003). Furthermore, invasive trophoblast cells are a source of IL-11 and IL-11R $\alpha$ during early pregnancy in primates, suggesting an involvement in placentation (Chen et al., 2002; Dimitriadis et al., 2003). In subsequent detailed studies of the receptor, immunoreactive IL-11R $\alpha$ was localized to the cell column and subpopulations of interstitial and endovascular EVT cells in vivo (Paiva et al., 2007).

The EVT-hybridoma cell line, AMI88, likewise expresses IL$11 \mathrm{R} \alpha$ but does not produce IL-11, thus providing a model to study effects of IL-11 on EVT. Both chemotactic migration and invasion are features of cellular movement through a tissue. IL-11 acted as a chemotactic agent in stimulating migration of the EVT-hybridoma cells (Fig. 4B) but was without effect on their proliferation. In primary EVT, blocking endogenous IL-11 inhibited EVT migration by $30-40 \%$, confirming the effect on migration is relevant in vivo (Paiva et al., 2007). Conversely, IL-11 significantly inhibited invasion of EVT cells by $40-60 \%$ and this IL-11-mediated inhibition occurred via STAT-3 and not MAPK signaling pathways. The
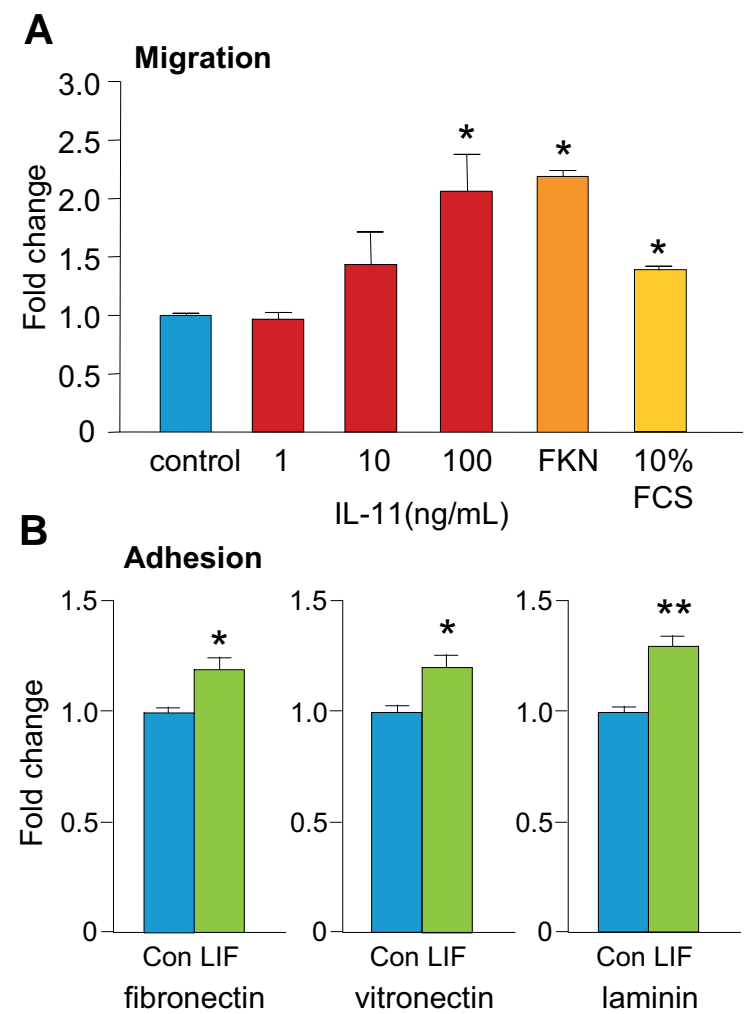

Fig. 4. Endometrial epithelial LIF and IL-11 have paracrine actions on trophoblast. (A) IL-11 stimulates migration of extravillous trophoblast cells in a dose dependent manner. CX3CL1 (Fractalkine, FKN) and fetal calf serum (FCS) which likewise stimulate migration, were used as positive controls. (B) LIF stimulates adhesion of extravillous trophoblast to the matrix components, fibronectin, vitronectin and laminin. (Reproduced with permission from Paiva et al., 2007; Tapia et al., 2008). 
mechanism by which IL-11 inhibits EVT invasion remains unclear since IL-11 had no effect on common protease systems (i.e. MMP2 or -9 , TIMPs $1-3$, the urokinase plasminogen activator system) and cell adhesive properties that are known to play important roles during EVT invasion (Paiva etal., 2008). This antiinvasive action of IL-11 is in contrast to its pro-invasive role during tumorigenesis of human cancers, reinforcing the tissue / cell specificity of such actions and the important role of decidua in restraining trophoblast invasion.

Chemokines have recently emerged as key players in directing migration of trophoblast using mechanisms akin to those used in leukocyte trafficking (Dominguez et al., 2002; Hannan and Salamonsen, 2007). Indeed, there are considerable similarities between the events of implantation, where trophoblast must attach and invade, and those of leukocyte extravasation from the lumen of the blood vessel, through the endothelial cell basal lamina and into tissue. Once the trophoblast has penetrated the epithelial layer it lies within the unique chemokine-rich environment. A wide range of chemokines are among the molecules that appear once decidualization of stromal cells has occurred, and their production by decidual cells continues throughout the first trimester. Several studies have demonstrated that EVT within first trimester decidua express several chemokine receptors, including CX3CR1, CCR1 and CCR3 (Hannan et al., 2006) and indeed, CCR1 appears to be switched on just as the EVT takes on invasive properties (Sato et al., 2003).

Trophoblast (EVT cell) migration has been demonstrated in response to CX3CL1, CCL14 and CCL4 and in particular, conditioned medium from both epithelial and decidualized but not nondecidualized stromal cells likewise stimulated trophoblast migration (Hannan et al., 2006). This was partly blocked by neutralization of CX3CL1 and CCL4, demonstrating that at least these two chemokines are likely to have such effects in vivo. This is in accord with other published work showing that CXCL12, CXCL16 and CCL12, that are also present in first trimester decidua, likewise stimulated migration (Red-Horse et al., 2001). Such cross talk from decidual cells to trophoblast at the maternal fetal interface also appears to occur in reverse (Hess et al., 2007).

Chemokine regulation of leukocyte trafficking is via regulation of adhesion molecules: similar mechanisms have now been demonstrated to apply also to trophoblast migration. Alterations in adhesion and extracellular matrix (ECM) molecules in response to chemokine stimulation of EVT were examined by pathway specific array analysis and findings validated by realtime RT-PCR, Significant changes in the mRNA transcripts of $\alpha$ catenin (CTNNA1), extracellular matrix protein-1 (ECM1), osteopontin (SPP1), integrin $\alpha 6$ (/TGA6), MMP12 (MMP12) and integrin $\beta 5$ (/TGB5) followed treatment by CXCL2 and/or CCL14. Immunohistochemistry confirmed the presence of integrin $\alpha 6$, SPP1 and ECM1 protein in first trimester human implantation sites (Hannan and Salamonsen, 2008). This inter-related temporal and spatial expression of chemokines, their receptors, adhesion and ECM at the maternal-fetal interface emphasizes an important role in the controlled directional migration of trophoblast through the maternal decidua.

\section{Conclusions}

It is of considerable interest that the same factors appear to be repetitively used, albeit by different cell types and with different functional outcomes, throughout the early stages of pregnancy in the human and also that factors which are expressed only in limited cell types during establishment of pregnancy in mice, are more widely expressed and over a longer relative time span in humans. Apparently the same regulatory molecules are adapted for different functions in different physiological situations. It is to be hoped that understanding the actions of these molecules throughout the establishment of pregnancy, will inform choices for targets for therapeutic interventions to reduce the impact of infertility and of pregnancy-related problems such as early miscarriage or inadequate placentation and the resultant pre-eclampsia.

\section{Acknowledgements}

The authors thank Dianne Arnold for assistance in preparation of this manuscript. Work in the authors' laboratories is supported by the National Health and Medical Research Council of Australia, grants \#388901, \#388916, \#441117, \#494802, and \#494808.

\section{References}

AGHAJANOVA, L., STAVREUS-EVERS, A., NIKAS, Y., HOVATTA, O. and LANDGREN, B.M. (2003). Coexpression of pinopodes and leukemia inhibitory factor, as well as its receptor, in human endometrium. Fertil Steril79 Suppl 1: 808-814.

APLIN, J.D. (1997). Adhesion molecules in implantation. Rev Reprod 2: 84-93.

APLIN, J.D., MESEGUER, M., SIMON, C., ORTIZ, M.E., CROXATTO, H. and JONES, C.J. (2001). Muc1, glycans and the cell-surface barrier to embryo implantation. Biochem Soc Trans 29: 153-156.

ARICI, A., ENGIN, O., ATTAR, E. and OLIVE, D.L. (1995). Modulation of leukemia inhibitory factor gene expression and protein biosynthesis in human endometrium. $J$ Clin Endocrinol Metab 80: 1908-1915.

BAIRD, D.T., CAMERON, S.T., CRITCHLEY, H.O., DRUDY, T.A., HOWE, A., JONES, R.L., LEA, R.G. and KELLY, R.W. (1996). Prostaglandins and menstruation. Eur J Obstet Gynecol Reprod Bio/70: 15-17.

BERGERON, F., LEDUC, R. and DAY, R. (2000). Subtilase-like pro-protein convertases: From molecular specificity to therapeutic applications. $J \mathrm{Mol}$ Endocrino/24: 1-22.

BHATT, H., BRUNET, L.J. and STEWART, C.L. (1991). Uterine expression of leukemia inhibitory factor coincides with the onset of blastocyst implantation. Proc Natl Acad Sci USA 88: 11408-11412.

BILINSKI, P., ROOPENIAN, D. and GOSSLER, A. (1998). Maternal IL-11Ralpha function is required for normal decidua and fetoplacental development in mice. Genes Dev 12: 2234-2243.

BOOMSMA, C.M., KAVELAARS, A., M.J., E., TEKLENBURG, G., FAUSER, B.C., HEIJNEN, C. and MACKLON, N.S. (2008). Analysis of endometrial secretions to predict pregnancy following ART. Reproductive Sciences 15 Suppl: 145A.

CARSON, D.D., LAGOW, E., THATHIAH, A., AL-SHAMI, R., FARACH-CARSON, M.C., VERNON, M., YUAN, L., FRITZ, M.A. and LESSEY, B. (2002). Changes in gene expression during the early to mid-luteal (receptive phase) transition in human endometrium detected by high-density microarray screening. Mol Hum Reprod 8: 871-879.

CHARNOCK-JONES, D.S., SHARKEY, A.M., FENWICK, P. and SMITH, S.K. (1994). Leukaemia inhibitory factor mRNA concentration peaks in human endometrium at the time of implantation and the blastocyst contains mRNA for the receptor at this time. $J$ Reprod Fertil 101: 421-426.

CHEN, H.F., LIN, C.Y., CHAO, K.H., WU, M.Y., YANG, Y.S. and HO, H.N. (2002). Defective production of interleukin-11 by decidua and chorionic villi in human anembryonic pregnancy. J Clin Endocrinol Metab 87: 2320-2328.

CORK, B.A., LI, T.C., WARREN, M.A. and LAIRD, S.M. (2001). Interleukin-11 (IL11 ) in human endometrium: Expression throughout the menstrual cycle and the effects of cytokines on endometrial IL-11 production in vitro. JReprod Immunol 50: 3-17.

CORK, B.A., TUCKERMAN, E.M., LI, T.C. and LAIRD, S.M. (2002). Expression of interleukin (IL)-11 receptor by the human endometrium in vivo and effects of IL- 
11, IL-6 and LIF on the production of MMP and cytokines by human endometrial cells in vitro. Mol Hum Reprod 8: 841-848.

CULLINAN, E.B., ABBONDANZO, S.J., ANDERSON, P.S., POLLARD, J.W., LESSEY, B.A. and STEWART, C.L. (1996). Leukemia inhibitory factor (LIF) and LIF receptor expression in human endometrium suggests a potential autocrine/ paracrine function in regulating embryo implantation. Proc Nat/ Acad Sci USA 93: 3115-3120.

DANIELSSON, K.G., SWAHN, M.L. and BYGDEMAN, M. (1997). The effect of various doses of mifepristone on endometrial leukaemia inhibitory factor expression in the midluteal phase-an immunohistochemical study. Hum Reprod 12: 1293-1297.

DELAGE, G., MOREAU, J.F., TAUPIN, J.L., FREITAS, S., HAMBARTSOUMIAN, E., OLIVENNES, F., FANCHIN, R., LETUR-KONIRSCH, H., FRYDMAN, R. and CHAOUAT, G. (1995). In-vitro endometrial secretion of human interleukin for DA cells/leukaemia inhibitory factor by explant cultures from fertile and infertile women. Hum Reprod 10: 2483-2488.

DIMITRIADIS, E., ROBB, L., LIU, Y.X., ENDERS, A.C., MARTIN, H., STOIKOS, C. WALLACE, E. and SALAMONSEN, L.A. (2003). IL-11 and IL-11Ralpha immunolocalisation at primate implantation sites supports a role for IL-11 in placentation and fetal development. Reprod Biol Endocrino/1: 34.

DIMITRIADIS, E., ROBB, L. and SALAMONSEN, L.A. (2002). Interleukin 11 advances progesterone-induced decidualization of human endometrial stromal cells. Mol Hum Reprod 8: 636-643.

DIMITRIADIS, E., SALAMONSEN, L.A. and ROBB, L. (2000). Expression of interleukin-11 during the human menstrual cycle: Coincidence with stromal cell decidualization and relationship to leukaemia inhibitory factor and prolactin. Mo/ Hum Reprod 6: 907-914.

DIMITRIADIS, E., SHARKEY, A.M., TAN, Y.L., SALAMONSEN, L.A. and SHERWIN, J.R. (2007a). Immunolocalisation of phosphorylated Stat3, interleukin 11 and leukaemia inhibitory factor in endometrium of women with unexplained infertility during the implantation window. Reprod Biol Endocrino/5: 44.

DIMITRIADIS, E., STOIKOS, C., BACA, M., FAIRLIE, W.D., MCCOUBRIE, J.E. and SALAMONSEN, L.A. (2005). Relaxin and prostaglandin E(2) regulate interleukin 11 during human endometrial stromal cell decidualization. J Clin Endocrinol Metab 90: 3458-3465.

DIMITRIADIS, E., STOIKOS, C., STAFFORD-BELL, M., CLARK, I., PAIVA, P., KOVACS, G. and SALAMONSEN, L.A. (2006a). Interleukin-11, IL-11 receptor alpha and leukemia inhibitory factor are dysregulated in endometrium of infertile women with endometriosis during the implantation window. J Reprod Immuno/ 69: 53-64.

DIMITRIADIS, E., STOIKOS, C., TAN, Y.L. and SALAMONSEN, L.A. (2006b). Interleukin 11 signaling components signal transducer and activator of transcription 3 (Stat3) and suppressor of cytokine signaling 3 (SOCS3) regulate human endometrial stromal cell differentiation. Endocrinology 147: 3809-3817.

DOMINGUEZ, F., GALAN, A., MARTIN, J.J., REMOHI, J., PELLICER, A. and SIMON, C. (2003). Hormonal and embryonic regulation of chemokine receptors CXCR1, CXCR4, CCR5 and CCR2b in the human endometrium and the human blastocyst. Mol Hum Reprod 9: 189-198.

DOMINGUEZ, F., PELLICER, A. and SIMON, C. (2002). Paracrine dialogue in implantation. Mol Cell Endocrinol 186: 175-181.

DUNGLISON, G.F., BARLOW, D.H. and SARGENT, I.L. (1996). Leukaemia inhibitory factor significantly enhances the blastocyst formation rates of human embryos cultured in serum-free medium. Hum Reprod 11: 191-196.

EVANS, J., CATALANO, R.D., MORGAN, K., CRITCHLEY, H.O., MILLAR, R.P. and JABBOUR, H.N. (2008). Prokineticin 1 signaling and gene regulation in early human pregnancy. Endocrinology 149: 2877-2887.

FLORIO, P., SEVERI, F.M., LUISI, S., CIARMELA, P., CALONACI, G., COBELLIS, L. and PETRAGLIA, F. (2003). Endometrial expression and secretion of activin A, but not follistatin, increase in the secretory phase of the menstrual cycle. $J$ Soc Gynecol Investig 10: 237-243.

FREYER, C., KILPATRICK, L.M., SALAMONSEN, L.A. and NIE, G. (2007). Proprotein convertases (PCs) other than PC6 are not tightly regulated for implantation in the human endometrium. Reproduction 133: 1189-1197.

FUGERE, M. and DAY, R. (2005). Cutting back on pro-protein convertases: The latest approaches to pharmacological inhibition. Trends Pharmaco/Sci26:294301.

GIPSON, I.K., BLALOCK, T., TISDALE, A., SPURR-MICHAUD, S., ALLCORN, S.,
STAVREUS-EVERS, A. and GEMZELL, K. (2008). MUC16 is lost from the uterodome (pinopode) surface of the receptive human endometrium: In vitro evidence that MUC16 is a barrier to trophoblast adherence. Biol Reprod78: 134142.

GIUDICE, L.C. (2003). Elucidating endometrial function in the post-genomic era. Hum Reprod Update. 9: 223-235.

GIUDICE, L.C. and IRWIN, J.C. (1999). Roles of the insulin like growth factor family in nonpregnant human endometrium and at the decidual: Trophoblast interface. Semin Reprod Endocrino/17: 13-21.

HANNAN, N.J., JONES, R.L., CRITCHLEY, H.O., KOVACS, G.J., ROGERS, P.A., AFFANDI, B. and SALAMONSEN, L.A. (2004). Coexpression of fractalkine and its receptor in normal human endometrium and in endometrium from users of progestin-only contraception supports a role for fractalkine in leukocyte recruitment and endometrial remodeling. J Clin Endocrinol Metab 89: 6119-6129.

HANNAN, N.J., JONES, R.L., WHITE, C.A. and SALAMONSEN, L.A. (2006). The chemokines, CX3CL1, CCL14, and CCL4, promote human trophoblast migration at the feto-maternal interface. Biol Reprod 74: 896-904.

HANNAN, N.J. and SALAMONSEN, L.A. (2007). Role of chemokines in the endometrium and in embryo implantation. Curr Opin Obstet Gyneco/19: 266272.

HANNAN, N.J. and SALAMONSEN, L.A. (2008). CX3CL1 and CCL14 regulate extracellular matrix and adhesion molecules in the trophoblast: Potential roles in human embryo implantation. Biol Reprod 79: 58-65.

HANNAN, N.J., PAIVA, P., DIMITRIADIS, E. and SALAMONSEN, L.A. (2009) Models for study of human embryo implantation: choice of cell lines? Biol Reprod (Epub ahead of print) (DOI:10.1095/biolreprod.109.077800)

HEINRICH, P.C., BEHRMANN, I., MULLER-NEWEN, G., SCHAPER, F. and GRAEVE, L. (1998). Interleukin-6-type cytokine signalling through the gp130/ Jak/Stat pathway. Biochem J334: 297-314.

HESS, A.P., HAMILTON, A.E., TALBI, S., DOSIOU, C., NYEGAARD, M., NAYAK N., GENBECEV-KRTOLICA, O., MAVROGIANIS, P., FERRER, K., KRUESSEL, J. et al. (2007). Decidual stromal cell response to paracrine signals from the trophoblast: Amplification of immune and angiogenic modulators. Biol Reprod 76: $102-117$

HU, W., FENG, Z., TERESKY, A.K. and LEVINE, A.J. (2007). P53 regulates maternal reproduction through LIF. Nature 450: 721-724.

JONES, R.L., HANNAN, N.J., KAITU'U, T.J., ZHANG, J. and SALAMONSEN, L.A. (2004). Identification of chemokines important for leukocyte recruitment to the human endometrium at the times of embryo implantation and menstruation. $J$ Clin Endocrinol Metab 89: 6155-6167

KALUS, I., SCHNEGELSBERG, B., SEIDAH, N.G., KLEENE, R. and SCHACHNER M. (2003). The proprotein convertase PC5A and a metalloprotease are involved in the proteolytic processing of the neural adhesion molecule I1. J Biol.Chem. 278: 10381-10388.

KAO, L.C., TULAC, S., LOBO, S., IMANI, B., YANG, J.P., GERMEYER, A., OSTEEN, K., TAYLOR, R.N., LESSEY, B.A. and GIUDICE, L.C. (2002). Global gene profiling in human endometrium during the window of implantation. Endocrinology 143: 2119-2138.

KARPOVICH, N., CHOBOTOVA, K., CARVER, J., HEATH, J.K., BARLOW, D.H. and MARDON, H.J. (2003). Expression and function of interleukin-11 and its receptor alpha in the human endometrium. Mol Hum Reprod 9: 75-80.

KARPOVICH, N., KLEMMT, P., HWANG, J.H., MCVEIGH, J.E., HEATH, J.K., BARLOW, D.H. and MARDON, H.J. (2005). The production of interleukin-11 and decidualization are compromised in endometrial stromal cells derived from patients with infertility. J Clin Endocrinol Metab 90: 1607-1612.

KOJIMA, K., KANZAKI, H., IWAI, M., HATAYAMA, H., FUJIMOTO, M., INOUE, T., HORIE, K., NAKAYAMA, H., FUJITA, J. and MORI, T. (1994). Expression of leukemia inhibitory factor in human endometrium and placenta. Bio/Reprod50: 882-887.

KOJIMA, K., KANZAKI, H., IWAI, M., HATAYAMA, H., FUJIMOTO, M., NARUKAWA, S., HIGUCHI, T., KANEKO, Y., MORI, T. and FUJITA, J. (1995). Expression of leukaemia inhibitory factor (LIF) receptor in human placenta: A possible role for LIF in the growth and differentiation of trophoblasts. Hum Reprod 10: 19071911.

LAIRD, S.M., TUCKERMAN, E.M., DALTON, C.F., DUNPHY, B.C., LI, T.C. and ZHANG, X. (1997). The production of leukaemia inhibitory factor by human 
endometrium: Presence in uterine flushings and production by cells in culture. Hum Reprod 12: 569-574.

LEDEE-BATAILLE, N. (2004). [secreted cytokines in the uterine lumina are predictive of subsequent implantation. Presence of IL18 in the uterine flushing]. $J$ Gynecol Obstet Biol Reprod (Paris) 33: S29-S32.

LEDEE-BATAILLE, N., LAPREE-DELAGE, G., TAUPIN, J.L., DUBANCHET, S., FRYDMAN, R. and CHAOUAT, G. (2002). Concentration of leukaemia inhibitory factor (LIF) in uterine flushing fluid is highly predictive of embryo implantation. Hum Reprod 17: 213-218.

LESSEY, B.A. (2002). Adhesion molecules and implantation. JReprod Immuno/55: 101-112.

LICHT, P., FLUHR, H., NEUWINGER, J., WALLWIENER, D. and WILDT, L. (2007). Is human chorionic gonadotropin directly involved in the regulation of human implantation? Mol Cell Endocrino/269: 85-92.

LISSITZKY, J.-C., LUIS, J., MUNZER, J.S., BENJANNET, S., PARAT, F., CHRETIEN, M., MARVALDI, J. and SEIDAH, N. (2000). Endoproteolytic processing of integrin pro-a subunits involves the redundant function of furin and proprotein convertase (PC) $5 \mathrm{~A}$, but not paired basic amino acid converting enzyme (pace) 4, PC5B or PC7. Biochem. J. 346: 133-138.

MAKKAR, G., NG, E.H., YEUNG, W.S. and HO, P.C. (2006). Reduced expression of interleukin-11 and interleukin- 6 in the periimplantation endometrium of excessive ovarian responders during in vitro fertilization treatment. $J$ Clin Endocrinol Metab 91: 3181-3188.

MARWOOD, M., VISSER, K., SALAMONSEN, L.A. and DIMITRIADIS, E. (2009) Interleukin 11 and leukemia inhibitory factor regulate the adhesion of endometrial epithelial cells; implications in fertility regulation. Endocrinology 150: 29152923.

MAYER, G., HAMELIN, J., ASSELIN, M.-C., PASQUATO, A., MARCINKIEWICZ, E., TANG, M., TABIBZADEH, S. and SEIDAH, N.G. (2008). The regulated cell surface zymogen activation of the proprotein convertase PC5A directs the processing of its secretory substrates. J. Biol. Chem. 283: 2373-2384.

MIKOLAJCZYK, M., SKRZYPCZAK, J., SZYMANOWSKI, K. and WIRSTLEIN, P. (2003). The assessment of LIF in uterine flushing-a possible new diagnostic tool in states of impaired fertility. Reprod Bio/3: 259-70.

MURPHY, C.R. (2004). Uterine receptivity and the plasma membrane transformation. Cell Res 14: 259-67.

NIE, G., KILPATRICK, L., STEPHENS, A., CHEN, J., STANTON, P. and SALAMONSEN, L. (2008). Proteomic identification of proprotein convertase 6 substrates in human endometrial stromal cells during decidualization. In: Abstracts of the $41^{\text {st }}$ Annual Meeting of the Society for the Study of Reproduction. Biol Reprod Special Issue, p.64.

NIE, G., LI, Y. and SALAMONSEN, L.A. (2005a). Serine protease HtrA1 is developmentally regulated in trophoblast and uterine decidual cells during placental formation in the mouse. Dev Dyn 233: 1102-1109.

NIE, G., LI, Y., WANG, M., LIU, Y.X., FINDLAY, J.K. and SALAMONSEN, L.A. (2005b). Inhibiting uterine PC6 blocks embryo implantation: An obligatory role for a proprotein convertase in fertility. Biol Reprod 72: 1029-36.

NIE, G.Y., LI, Y., MINOURA, H., FINDLAY, J.K. and SALAMONSEN, L.A. (2003). Specific and transient up-regulation of proprotein convertase 6 at the site of embryo implantation and identification of a unique transcript in mouse uterus during early pregnancy. Biol Reprod 68: 439-47.

OKADA, H., NIE, G. and SALAMONSEN, L.A. (2005). Requirement for proprotein convertase $5 / 6$ during decidualization of human endometrial stromal cells in vitro. J Clin Endocrinol Metab 90: 1028-1034.

PAIVA, P., SALAMONSEN, L., MANUELPILLAI, U. and DIMITRIADIS, E. (2009). Interleukin 11 inhibits human trophoblast invasion indicating a likely role in the decidual restraint of trophoblast invasion during placentation. Biol Reprod80: 302-310.

PAIVA, P., SALAMONSEN, L.A., MANUELPILLAI, U., WALKER, C., TAPIA, A., WALLACE, E.M. and DIMITRIADIS, E. (2007). Interleukin-11 promotes migration, but not proliferation, of human trophoblast cells, implying a role in placentation. Endocrinology 148: 5566-5572.

PARMAR, T., SACHDEVA, G., SAVARDEKAR, L., KATKAM, R.R., NIMBKARJOSHI, S., GADKAR-SABLE, S., SALVI, V., MANJRAMKAR, D.D., MEHERJI, P. and PURI, C.P. (2008). Protein repertoire of human uterine fluid during the mid-secretory phase of the menstrual cycle. Hum Reprod 23: 379-386.
PERRIER D'HAUTERIVE, S., CHARLET-RENARD, C., BERNDT, S., DUBOIS, M., MUNAUT, C., GOFFIN, F., HAGELSTEIN, M.T., NOEL, A., HAZOUT, A., FOIDART, J.M. et al. (2004). Human chorionic gonadotropin and growth factors at the embryonic-endometrial interface control leukemia inhibitory factor (LIF) and interleukin 6 (IL-6) secretion by human endometrial epithelium. Hum Reprod 19: 2633-2643.

POPOVICI, R.M., KAO, L.C. and GIUDICE, L.C. (2000). Discovery of new inducible genes in in vitrodecidualized human endometrial stromal cells using microarray technology. Endocrinology 141: 3510-3513.

RED-HORSE, K., DRAKE, P.M., GUNN, M.D. and FISHER, S.J. (2001). Chemokine ligand and receptor expression in the pregnant uterus: Reciprocal patterns in complementary cell subsets suggest functional roles. Am J Patho/159: 2199 2213.

REISTER, F., KINGDOM, J.C., RUCK, P., MARZUSCH, K., HEYL, W., PAUER, U., KAUFMANN, P., RATH, W. and HUPPERTZ, B. (2006). Altered protease expression by periarterial trophoblast cells in severe early-onset preeclampsia with IUGR. J Perinat Med 34: 272-279.

RIESEWIJK, A., MARTIN, J., VAN OS, R., HORCAJADAS, J.A., POLMAN, J., PELLICER, A., MOSSELMAN, S. and SIMON, C. (2003). Gene expression profiling of human endometrial receptivity on days $\mathrm{LH}+2$ versus $\mathrm{LH}+7$ by microarray technology. Mol Hum Reprod 9: 253-264.

ROBB, L., LI, R., HARTLEY, L., NANDURKAR, H.H., KOENTGEN, F. and BEGLEY, C.G. (1998). Infertility in female mice lacking the receptor for interleukin 11 is due to a defective uterine response to implantation. Nat Med 4: 303-308.

SATO, Y., HIGUCHI, T., YOSHIOKA, S., TATSUMI, K., FUJIWARA, H. and FUJII, S. (2003). Trophoblasts acquire a chemokine receptor, CCR1, as they differentiate towards invasive phenotype. Development 130: 5519-5532.

SAWAI, K., MATSUZAKI, N., KAMEDA, T., HASHIMOTO, K., OKADA, T., SHIMOYA, K., NOBUNAGA, T., TAGA, T., KISHIMOTO, T. and SAJI, F. (1995). Leukemia inhibitory factor produced at the fetomaternal interface stimulates chorionic gonadotropin production: Its possible implication during pregnancy, including implantation period. J Clin Endocrinol Metab 80: 1449-1456.

SAWAI, K., MATSUZAKI, N., OKADA, T., SHIMOYA, K., KOYAMA, M., AZUMA, C. SAJI, F. and MURATA, Y. (1997). Human decidual cell biosynthesis of leukemia inhibitory factor: Regulation by decidual cytokines and steroid hormones. Biol Reprod56: 1274-1280.

SEIDAH, N. and CHRETIEN, M. (1999). Proprotein and prohormone convertases: A family of subtilases generating diverse bioactive polypeptides. Brain Res 848 : 45-62.

SEIDAH, N.G., MAYER, G., ZAID, A., ROUSSELET, E., NASSOURY, N., POIRIER S., ESSALMANI, R. and PRAT, A. (2008). The activation and physiological functions of the proprotein convertases. Int J Biochem Cel/ Bio/40: 1111-1125.

SHARKEY, A.M., DELLOW, K., BLAYNEY, M., MACNAMEE, M., CHARNOCKJONES, S. and SMITH, S.K. (1995). Stage-specific expression of cytokine and receptor messenger ribonucleic acids in human preimplantation embryos. Biol Reprod 53: 974-981

SHARKEY, A.M., KING, A., CLARK, D.E., BURROWS, T.D., JOKHI, P.P., CHARNOCK-JONES, D.S., LOKE, Y.W. and SMITH, S.K. (1999). Localization of leukemia inhibitory factor and its receptor in human placenta throughou pregnancy. Biol Reprod60: 355-364.

SHARKEY, A.M. and SMITH, S.K. (2003). The endometrium as a cause of implantation failure. Best Pract Res Clin Obstet Gynaecol 17: 289-307.

SHERWIN, J.R., SMITH, S.K., WILSON, A. and SHARKEY, A.M. (2002). Soluble gp130 is up-regulated in the implantation window and shows altered secretion in patients with primary unexplained infertility. J Clin Endocrino/Metab87: 39533960.

STAWOWY, P., KALLISCH, H., VEINOT, J.P., KILIMNIK, A., PRICHETT, W. GOETZE, S., SEIDAH, N.G., CHRETIEN, M., FLECK, E. and GRAF, K. (2004). Endoproteolytic activation of \{alpha\} $v$ integrin by proprotein convertase $\mathrm{PC} 5$ is required for vascular smooth muscle cell adhesion to vitronectin and integrindependent signaling. Circulation 109: 770-776.

STEWART, C.L., KASPAR, P., BRUNET, L.J., BHATT, H., GADI, I., KONTGEN, F. and ABBONDANZO, S.J. (1992). Blastocyst implantation depends on maternal expression of leukaemia inhibitory factor. Nature 359: 76-79.

TAPIA, A., SALAMONSEN, L.A., MANUELPILLAI, U. and DIMITRIADIS, E. (2008). Leukemia inhibitory factor promotes human first trimester extravillous trophoblast adhesion to extracellular matrix and secretion of tissue inhibitor of 
metalloproteinases-1 and -2. Hum Reprod. 23: 1724-1732.

TIERNEY, E.P., TULAC, S., HUANG, S.T. and GIUDICE, L.C. (2003). Activation of the protein kinase a pathway in human endometrial stromal cells reveals sequential categorical gene regulation. Physiol Genomics 16: 47-66.

TSAI, H.D., CHANG, C.C., HSIEH, Y.Y. and LO, H.Y. (2000). Leukemia inhibitory factor expression in different endometrial locations between fertile and infertile women throughout different menstrual phases. JAssist Reprod Genet 17: 415418.

VOGIAGIS, D., MARSH, M.M., FRY, R.C. and SALAMONSEN, L.A. (1996). Leukaemia inhibitory factor in human endometrium throughout the menstrual cycle. J Endocrino/148: 95-102.

WHITE, C.A., DIMITRIADIS, E., SHARKEY, A.M. and SALAMONSEN, L.A. (2005) Interleukin-11 inhibits expression of insulin-like growth factor binding protein-5 mRNA in decidualizing human endometrial stromal cells. Mol Hum Reprod11: 649-658.

WHITE, C.A., ZHANG, J.G., SALAMONSEN, L.A., BACA, M., FAIRLIE, W.D. METCALF, D., NICOLA, N.A., ROBB, L. and DIMITRIADIS, E. (2007). Blocking LIF action in the uterus by using a PEGylated antagonist prevents implantation: A nonhormonal contraceptive strategy. Proc Nat/ Acad Sci USA 104: $19357-$ 19362.

\section{Further Related Reading, published previously in the Int. J. Dev. Biol.}

See our recent Special Issue Epigenetics \& Development edited by Saadi Khochbin and Stefan Nonchev at: http://www.ijdb.ehu.es/web/contents.php?vol=53\&issue=2-3

See Special Issue Pattern Formation edited by Michael K. Richardson and Cheng-Ming Chuong at: http://www.ijdb.ehu.es/web/contents.php?vol=53\&issue=5-6

The influence of the intrauterine environment on human placental development Graham J. Burton, Eric Jauniaux and D. Stephen Charnock-Jones Int. J. Dev. Biol. (2010) 54: 303-312 (doi: 10.1387/ijdb.082764gb)

A simple in vivo approach to investigate invasive trophoblast cells Juan A. Arroyo, Toshihiro Konno, Darya C. Khalili and Michael J. Soares Int. J. Dev. Biol. (2005) 49: 977-980

Implantation: molecular basis of embryo-uterine dialogue.

B C Paria, $\mathrm{H}$ Song and S K Dey

Int. J. Dev. Biol. (2001) 45: 597-605

Expression pattern of different gap junction connexins is related to embryo implantation. R Grümmer, B Reuss and E Winterhager Int. J. Dev. Biol. (1996) 40: 361-367

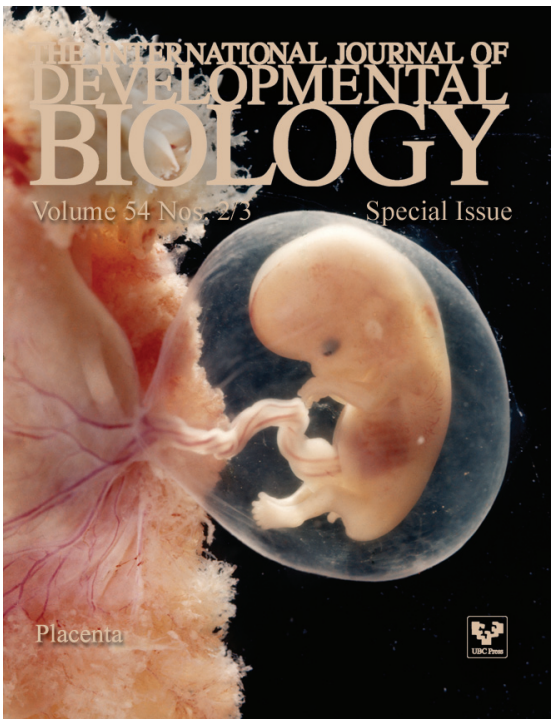

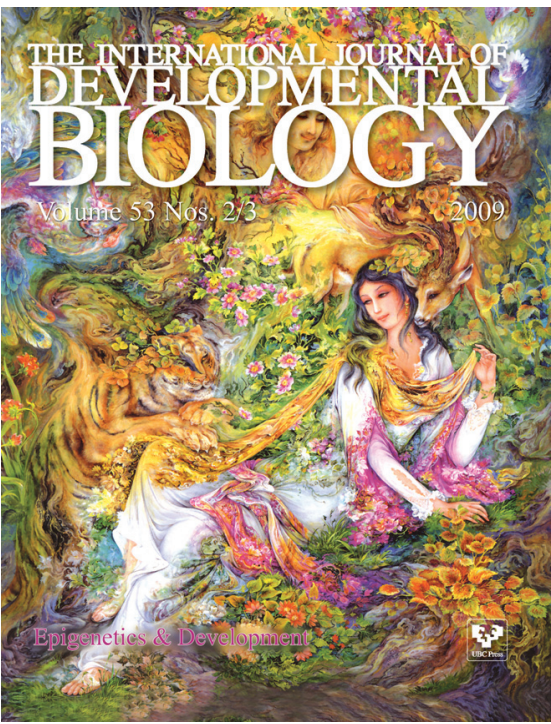

5 yr ISI Impact Factor $(2008)=3.271$

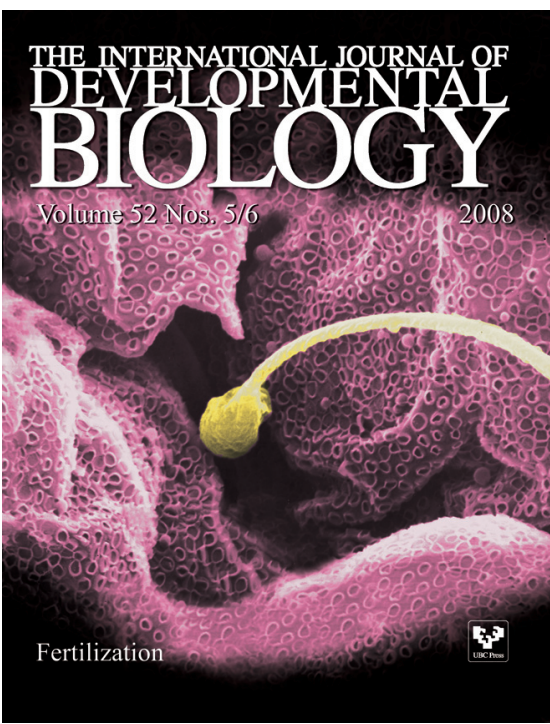

